\title{
Communication Processes and Relationships
}

\section{Robyn Penman}

October 1980, viii + 156pp., f9.80 (UK on/y)/\$23.00,0.12.550380.6

The study of human relationships requires an analysis of the way people communicate, since it is by communicating that we initiate, maintain and change our relationships with others. The analysis of communication has been undertaken both by social psychologists and by information and communications scientists. This book integrates the contributions made by these disciplines and proposes a new method of examining communications and hence relationships.

\section{How Twins Learn to Talk}

A Study of the Speech Development of Twins from 1 to 3

Svenka Savic

September 1980, xvi + 196pp., E15.00 (UK only)/\$34.50, 0.12.619580 3

Within the field of child language studies, there are few areas that have given rise to as much speculation and debate amongst non-specialists as the speech habits of twins. There are numerous theories but few hard facts: Dr Savic's book provides concrete answers to a number of basic.questions.

\section{Academic Press}

A Subsidiary of Harcourt Brace Jovanovich, Publishers London New York Toronto Sydney San Francisco 24-28 Oval Road. London NW1 7DX. England 111 Fifth Avenue, New York, NY 10003, USA 


\section{CAMBRIDGE}

\section{Language in the USA}

\section{Charles A. Ferguson and Shirley Brice Heath, Editors}

with a Foreword by Dell H. Hymes

Twenty-three specially commissioned essays survey the history, varieties, and current status of the languages of the United States. Contributors discuss American English, native American languages. immigrant languages, and languages in the professions. Over 70 tables, diagrams, plates.

\section{Part I. American English}

Hardeover \$\$ \$ $\$ 00$ Paper \$14.95

essays by S.B. Heath. B.B. Kachru, W. Wolfram. P.C. Nichols, E. Whatley

Part II. Languages before English

essays by W.L. Leap, W. Walker, A.R. Taylor, J.R. Craddock

Part III. Languages after English

essays by A.C. Zentella, Y. Correa-Zoli, G.G. Gilbert, D.L. Gold, V.M. Henzl, J. \& M. Beebe, A.F. Beltramo

\section{Part IV. Language in Use}

essays by W.M. O'Barr, A.V. Cicourel, J.J. Gumperz, \& J. Cook-Gumperz, C.B. Cazden \&

D.K. Dickinson, C. Bratt Paulston, D. Waggoner, J.A. Fishman

\section{The Organization of Language}

\section{Janice Moulton and George M. Robinson}

Moulton and Robinson present an important new theory clarifying the relationship of language and thought. Their cognitive model of syntax and language acquisition and general analysis of language addresses such questions as: What are the essential features of language that permit a sentence to convey a complex idea? How do language users produce and understand meaningful sentences? What enables humans-and perhaps apes and robots-to learn this remarkable skill? Over 100 tables and diagrams.

Hardcover \$39.95 Paper \$14.95

\section{Universals of Human Thought Some African Evidence}

\section{Barbara Lloyd and John Gay, Editors}

An investigation into the existence of universals in the mental processes underlying social and cultural diversity. Essays focus on relevant data in Africa to examine the major questions, dealing respectively with perception, cognitive development, and language. With a general review and prospectus by Jerome Bruner, and an extensive introduction to the philosophical background by Ernest Ciellner. Hardcover \$ $\$ 7.50$ Paper $\$ 14.95$

\section{Old Church Slavonic}

An Elementary Grammar

s.c.. Ciardiner

\section{Dialectology}

J.K. Chambers and Peter Trudgill

Cambridge Textbooks in Linguistics Hardcover \$34.50 Paper $\$ 11.95$

The Phonetic Description of Voice Quality

John Laver CSL $3 I$

\section{Ngiyambaa}

The Language of the Wangaaybuwan

$\$ 16.95$ Tamsin Donaldson CSL.29 $\$ 59.50$

\section{Quantity in}

Historical Phonology

Icelandic and Related Cases

Kristján Arnason CSL 30 \$44.50)

CSL $=$ Cambridge Studies in Linguistics

all prices subject to change

\section{Cambridge University Press}


INSTRUCTIONS TO AUTHORS

Components and style of the manuscript

Authors of articles or notes should submit their original manuscript plus two copies to:

Sheldon Rosenberg, Editor

Applied Psycholinguistics

Department of Psychology

University of Illinois at Chicago Circle

Box 4348

Chicago, Illinois 60680

Full length articles (original research, theoretical or methodological studies, literature reviews) should not exceed 14,000 words. Shorter notes may be, for instance, reports of work in progress or critical responses to articles or notes previously published in Applied Psycholinguistics

Spelling, capitalization, and punctuation should be consistent within each article and each note, and should follow the style recommended in the latest edition of the Publication Manual of the American Psychological Association. A title should be given for each article and note. An auxiliary short title should be given for any article or note whose title exceeds 50 characters. The author's name should be given in the form preferred for publication; the affiliation should include the author's full mailing address. An abstract should be prepared for each article (limited to 120 words) and note (limited to 60 words). Tables and figures (which comprise photographs, charts or other artwork) should be numbered consecutively throughout the article or note. Bibliographic citations in the text must include the author's last name and the date of publication and may include page references. Complete bibliographic information for each citation should be included in the list of references. Examples of correct styling for bibliographic citations are: Brown (1973), Ingram (1976, 54-55), Smith and Miller (1966), (Smith \& Miller, 1966), (Peterson, Danner \& Flavell, 1972) and subsequently (Peterson et al., 1972).

References should be typed in alphabetical order using the style of the following examples:

Brown, R. Schizophrenia, language and reality. American Psychologist, 1973, 28, 395-403.

Ingram, D. Phonological disability in children. New York: Elsevier, 1976.

Krashen, S.D. Individual variation in the use of the Monitor. In W.C. Ritchie (Ed.), Second language acquisition research. New York: Academic Press, 1978.

Smith, F., \& Miller, G.A. (Eds.), The genesis of language. Cambridge, Mass.: M.I.T. Press, 1966.

Titles of journals should not be abbreviated.

\section{Preparation of the manuscript}

The entire manuscript, including footnotes and references, should be typed double-spaced on $81 / 2$ by 11 inch or A4 paper, with margins set to accommodate approximately 70 characters per line and 25 lines per page, and should not exceed 50 typed pages. Each element of the article or note should begin on a new page and should be arranged as follows: title page (including title, short title, author's full name and affiliation, including mailing address), abstract, text with tables interspersed as they occur, appendixes, acknowledgements, footnotes, references (including reference notes for unpublished citations), captions and figures. Each table and figure should be submitted on a separate page. Manuscript pages should be numbered consecutively.

Figures should be ready for photographic reproduction; they cannot be redrawn by the printer. Charts, graphs, or other artwork should be drawn in black ink on white paper to occupy a standard area of $8 \frac{1}{2}$ by 11 or $8 \frac{1}{2}$ by $51 / 2$ inches before reduction. Photographs should be glossy black-and-white prints; 8 by 10 inch enlargements are preferred. All labels and details on figures should be clearly printed and large enough to remain legible after a reduction to half-size. It is recommended that labels be done in transfer type of a sans-serif face such as Helvetica.

\section{Copyediting and proofreading}

The publishers reserve the right to copyedit and proof all articles and notes accepted for publication. Authors will review their copyedited manuscripts only if changes have been substantial. Page proofs of articles and notes will be sent to authors for correction of typographical errors only; authors must notify the editorial office of any changes within 48 hours or approval will be assumed.

The latest edition of the Publication Manual of the American Psychological Association should be consulted for instructions on aspects of manuscript preparation and style not covered in these instructions. The Editor may find it necessary to return for reworking and retyping manuscripts that do not conform to requirements.

Each author will receive 25 offprints of his or her article or note without charge; additional copies may be purchased if ordered at proof stage.

Submission of an article or note implies that it has not been published elsewhere. Authors are responsible for obtaining written permission to publish material (quotations, illustrations, etc.) for which they do not own the copyright. Contributors of accepted articles and notes will be asked to assign their copyrights, on certain conditions, to Cambridge University Press. 


\section{Applied Psycholinguistics \\ Volume 2 Number 11981}

Editor's overview

HELEN TAGER-FLUSBERG Sentence comprehension in autistic children

STEVEN SCHWARTZ Language disabilities in infantile autism: A brief review and comment

JACQUELINE SACHS, BARBARA BARD, and MARIE L. JOHNSON Language learning with restricted input: Case studies of two hearing children of deaf parents

Z. S. BOND A note concerning /s/ plus stop clusters in the speech of language-delayed children

MARION BLANK and JANET MILEWSKI Applying psycholinguistic concepts to the treatment of an autistic child

๑Cambridge University Press 1981

\section{CAMBRIDGE UNIVERSITY PRESS}

The Pitt Building, Trumpington Street, Cambridge CB2 1RP, England 32 East 57 Street, New York, N.Y. 10022, USA

296 Beaconsfield Parade, Middle Park, Melbourne 3206, Australia 